\title{
Article \\ Substrate Stratification: Layering Unique Substrates within a Container Increases Resource Efficiency without Impacting Growth of Shrub Rose
}

\author{
Jeb S. Fields ${ }^{1, *}$, James S. Owen, Jr. ${ }^{2}$ and James E. Altland ${ }^{2}$ \\ 1 Hammond Research Station, Louisiana State University Agricultural Center, Hammond Research Station, \\ 21549 Old Covington Hwy., Hammond, LA 70403, USA \\ 2 Application Technology Research Unit, Agricultural Research Service, United States Department of \\ Agriculture, 1680 Madison Ave., Wooster, OH 44691, USA; jim.owen@usda.gov (J.S.O.J.); \\ james.altland@usda.gov (J.E.A.) \\ * Correspondence: jfields@agcenter.lsu.edu
}

Citation: Fields, J.S.; Owen, J.S., Jr.; Altland, J.E. Substrate Stratification: Layering Unique Substrates within a Container Increases Resource Efficiency without Impacting Growth of Shrub Rose. Agronomy 2021, 11, 1454. https://doi.org/10.3390/ agronomy11081454

Academic Editor: Anna Tedeschi

Received: 7 June 2021

Accepted: 19 July 2021

Published: 22 July 2021

Publisher's Note: MDPI stays neutral with regard to jurisdictional claims in published maps and institutional affiliations.

Copyright: (c) 2021 by the authors. Licensee MDPI, Basel, Switzerland. This article is an open access article distributed under the terms and conditions of the Creative Commons Attribution (CC BY) license (https:// creativecommons.org/licenses/by/ $4.0 /)$.

\begin{abstract}
Nurseries rely on soilless substrates to provide suitable growing media for container grown crops. These soilless substrates have been developed to readily drain water to prevent issues with waterlogging and associated soil-borne disease. A negative consequence of high porosity and subsequent drainage throughout the container profile is the required high or frequent irrigation rates with poor retention of applied nutrients. Substrates with relatively high levels of moisture and nutrient retention placed on top of a coarse and freely draining substrate could further optimize water and nutrient retention, while allowing for needed gas exchange for plant establishment and growth. Containerized Red Drift ${ }^{\circledR}$ rose (Rosa 'Meigalpio' PP17877) plants were grown under $16 \mathrm{~mm}$ or $12 \mathrm{~mm}$ daily irrigation, utilizing a traditional pine bark substrate or stratified substrates with either a conventional bark, bark fines, or a bark-peat mixture on top of a coarse bark within a container. The stratified substrates received $20 \%$ less controlled-release fertilizer; however, the fertilizer in the stratified treatments was concentrated in the upper strata only. During the first growing phase or season, plants grown in stratified substrates outperformed those grown in conventional, nonstratified bark substrates under normal irrigation. The stratified substrates did not reduce growth under reduced irrigation regimes. Overall, crop growth was equal or superior for stratified substrates when compared to the non-stratified controls, even with a $20 \%$ reduction of fertilizer. This research suggests that stratified substrate systems can be used to reduce fertilizer and irrigation rates while producing crops of similar or superior quality to conventionally grown containerized crops.
\end{abstract}

Keywords: Rosa; hydraulic distribution; irrigation; mineral nutrients; pine bark; sphagnum peat; substrate texture

\section{Introduction}

Nursery operations are intensely managed to provide high quantities of salable plants with minimum production time. Container plant production requires the use of relatively high amounts of fertilizer and agrichemicals when compared to field production [1]. The soilless substrate components utilized by the industry have relatively low air-filled porosity and high proportions of readily drained water in gravitational pores with low chemical retention or exchange capacity as compared to mineral soils on a volume basis, resulting in the need for more frequent water and fertilizer application compared to most field-grown crops. As such, excess water is often applied daily to containerized nursery crops to reduce the risk of crop water stress and subsequent crop loss [2]. Container nurseries have been estimated to consume upwards of $178 \mathrm{~m}^{3}$ of water per hectare per day during peak growing season [3]. This excess of applied water leads to increased runoff or leaching of applied agrichemicals such as mineral nutrients [4] and pesticides [5]. In the near future, more 
efficient practices will need to be developed to ensure a sustainable future for and the long-term success of the container nursery industry.

Nursery growers across the USA are currently facing regulations and restrictions associated with limiting water use [6]. Fulcher et al. [6] predict that water quality and availability will only become greater challenges in the future. As such, there is a general push to increase production sustainability. Additionally, growers are seeking more efficient production practices to gain economic benefits [7]. Caplan et al. [8] similarly reported the growers are more likely to adopt technologies to increase sustainability if they are aware of the associated economic benefits. Utilization of soilless substrates may be a feasible approach to reduce water and fertilizer requirements when producing container crops to increase profitability and improve or adopt sustainable production practices.

There is growing evidence that substrate engineering [9] can lead to more sustainable substrates by creating unique physiochemical characteristics [10] to address specific pitfalls in conventional substrates. Recent research has shown that designer or engineered substrates have the potential to reduce weed pressure [11], water use [12], nutrient leaching [13], pesticides leaching [14], and production times [15].

Substrate stratification refers to layering different substrates or different textures of the same substrate within a single container [16]. Stratification is a naturally occurring process in field soils, whereby individual soil horizons are formed from different parent materials [17]. The resulting layers or horizons contribute unique physical, chemical, and hydraulic characteristics to the soil profile. This concept has been transferred and exaggerated into manufactured soil systems such as rain gardens [18], athletic turf [19], wastewater treatment [20], bioretention systems [21], and other synthesized soil systems to provide specific functions. Applying stratification techniques into nursery container systems may present a variety of opportunities, including more efficient water, fertilizer, and pest management options.

Stratifying substrates allows for more precise fertilizer placement. Applying fertilizer to the top of the container reduces nutrient loss during plant establishment [22]. When mixing the substrate used for the top layer, fertilizer can be incorporated at a higher rate to compensate for the absence of fertilizer in the bottom layer. Incorporation in the top layer also prevents the controlled-release fertilizer (CRF) from spillage that commonly happens when plants are blown over from inclement weather and after CRF is applied to the surface as a top-dress. As such, we hypothesize that incorporating fertilizer only in the upper strata could reduce mineral nutrient losses though leaching and reduce the amount of applied fertilizer compared to incorporation throughout the profile, while preventing spillage issues that would arise from top-dressing.

Stratification of the substrate might also be used to create a more optimal air and water gradient for establishment and growth. The current industry practice of filling containers entirely with the same substrate results in the bottom portion of the container staying near container capacity or complete saturation, while the upper portion containing the plant drains rapidly and has less readily available water. These systems require excessive irrigation during establishment to maintain a rooted liner with a root ball measuring onethird to half the depth of the container; thus, it is hypothesized that modifying the substrate hydraulics in the upper growing layer will allow less irrigation (reducing irrigation volume and leachate) to supply needed water during the early growth and establishment stages. As the root system grows, it will access the lower strata, which will have greater air content and lower substrate volumetric water content (VWC). In theory, the air-to-water ratio in the coarse bottom strata would shift toward decreased air-filled porosity due to roots filling pores and changing the porosity [23,24].

The overarching goal of this research was to reduce input resources (i.e., water and mineral nutrients) with an engineered soilless substrate using two unique strata comprised of differing hydrophysical properties. This was accomplished through two specific objectives: (1) by assessing the water dynamics and gradient throughout stratified container 
substrates; (2) by determining whether stratified substrates could be used to produce plants with reduced water and fertilizer in a nursery setting.

\section{Materials and Methods}

\subsection{Substrate Processing}

Four substrate treatments were developed for the experiment, composed primarily of pine (Pinus taeda L.) bark sourced from a regional bark processor (Phillips Bark Processing Co., Brookhaven, MS, USA). The control (CTL), which is also utilized by regional nursery growers, was a conventional stabilized pine bark (aged approx. nine months) passed through a $16 \mathrm{~mm}$ screen and amended with dolomite $\left(4.5 \mathrm{~kg} \mathrm{~m}^{-3}\right.$; Imerys, Roswell, GA, USA), a 18N:2.6P:9.9K controlled-release fertilizer (CRF; 18-6P-12K Osmocote, 9-mo, ICL Specialty Fertilizers, Summerville, SC, USA), and micronutrients $\left(1.2 \mathrm{~kg} \mathrm{~m}^{-3}\right.$, Micromax, ICL Specialty Fertilizers, Summerville, SC, USA). The three remaining treatments were stratified within the container by filling the bottom half (determined by the vertical height of the filled portion of the container) with one substrate and the top half with another. The bottom half of all stratified treatments was a 75:25 blend (by vol.) of coarse bark ( $>12.6 \mathrm{~mm}$ ) and the above described conventional bark amended with lime $\left(4.5 \mathrm{~kg} \mathrm{~m}^{-3}\right)$ only. The upper strata consisted of either the above described conventional bark $(<16 \mathrm{~mm})$, bark fines ( $<6.3 \mathrm{~mm}$ particles), or bark-peat ( $65: 35$ by vol. ratio of the CTL bark and unamended sphagnum peat; Premier Tech, Quebec, CA, USA). Each of the top strata treatments were amended with 1.6x CRF and micronutrients of the CTL and lime incorporated at the same rate $\left(4.5 \mathrm{~kg} \mathrm{~m}^{-3}\right)$. As a result, the total fertilizer applied in the stratified containers was $0.8 \mathrm{x}$ of CTL, all of which was incorporated in the upper strata. The stratified substrate treatments will henceforth be referred to as Strat-Conventional (SC); Strat-Fines (SF); and Strat-Bark-Peat (SP).

\subsection{Substrate Hydrophysical Properties}

The static physical properties, including the air space (AS), container capacity (CC), total porosity $(\mathrm{TP})$, and bulk density $\left(\mathrm{D}_{\mathrm{b}}\right)$, were measured on three replicates of each substrate used in the various strata as described above, utilizing porometer analysis [25]. The particle size distribution of each substrate was measured on three oven-dried replicates of approximately $100 \mathrm{~g}$ by determining the mass of particles remaining on each sieve or in the pan after agitating with a Ro-Tap shaker (Rx-29; W.S. Tyler, Mentor, OH, USA) for five minutes. Sieve sizes were 6.30, 2.00, 0.71, 0.50, 0.25, and $0.11 \mathrm{~mm}$.

A Hyprop instrument (METER Group Inc., Pullman, WA, USA) was utilized to assess substrate moisture characteristic curves (MCC; relationship between substrate water potential and volumetric water content, VWC) via the evaporative method following procedures by Fields et al. [26]. Briefly, three individual $250 \mathrm{~cm}^{3}$ cores were packed with each individual substrate used in the various strata described above to a uniform $D_{b}$ approximately equal to that used in a container for production. Each sample was saturated and allowed to dry via evaporation, while substrate water tension $(h)$ was measured via tensiometry and VWC was calculated through mass balance. Measured values from the three replicates, including TP values assessed using the porometer (as saturated VWC), were used to fit hydraulic parameters with the Brooks and Corey model [27] using soil-water retention curve software [28]. Moisture characteristic models were then used to calculate easily available water (EAW; water held between $-10 \mathrm{hPa}$ and $-50 \mathrm{hPa}$ ), water buffering capacity (WBC; water held between $-50 \mathrm{hPa}$ and $-100 \mathrm{hPa}$ ), and available water [AW; water held between $-1.5 \mathrm{MPa}$ and $-5 \mathrm{hPa}(\mathrm{CC})]$ levels.

\subsection{Stratified Growth Experiment}

Twenty 11.3 L containers (C1200; Nursery Supplies, Kissimmee, FL, USA) for each of the four previously described substrate treatments were transplanted with a $10.2 \mathrm{~cm}$ Red Drift ${ }^{\circledR}$ rose (Rosa 'Meigalpio' PP17877) liner and placed on a simulated nursery pad at the Louisiana State University Agriculture Center Hammond Research Station. All 
plants received $16 \mathrm{~mm}$ of water daily through overhead irrigation for two weeks to ensure establishment, after which half of the replicates from each substrate treatment (10 replicates) were moved to a second irrigation zone receiving $12 \mathrm{~mm}$ daily (reduced), while the remaining plants were kept at $16 \mathrm{~mm}$ daily (normal). The irrigation zones were not replicated for practical reasons; therefore, differences across irrigation treatments will not be compared statistically but will be discussed. Here, $0.19 \pm 0.08$ and $0.05 \pm 0.004$ leaching fractions (vol. of water leached/vol. water applied, per container) were measured on replicates with the CTL substrate under normal and reduced irrigation treatments, respectively, at the beginning of the project. Growth indices ((shoot height + widest width + perpendicular width)/3) were measured approx. every 20 days on five randomly selected replicates of each substrate. Substrate pore water fertility (electrical conductivity (EC) and $\mathrm{pH}$ )) was assessed via pour-through analysis [29], wherein containers were over-irrigated to reach effective CC, allowed to equilibrate for $1 \mathrm{~h}$, then $250 \mathrm{~mL}$ deionized water was applied to the substrate surface. Substrate pore water was displaced from the container, collected in a pan, and $\mathrm{pH}$ and EC extracts were measured using a portable electrochemical probe (GroLine probe; HI9814K; Hanna Instruments, Smithfield, RI, USA). Plants were grown until daytime temperatures cooled (125 days), at which point half the replicates of each of the eight substrate $x$ irrigation treatments were harvested.

\subsection{Harvest}

Plants were photographed 125 days after initiation (DAI). Foliar samples from half of the replicates in each treatment (five) were collected and the plants were then destructively harvested with shoots separated from roots and washed of substrate. All tissue samples were dried for $5 \mathrm{~d}$ at $70{ }^{\circ} \mathrm{C}$ and weighed. Dry mass from foliar samples were then added back to the shoot mass. The remainder of the replicates (five) were trimmed evenly with hand pruners to a height of $23 \pm 2 \mathrm{~cm}$ in accordance with nursery procedures, clippings were dried and weighed, then replicates were moved to an overwinter structure. On 280 DAI, plants were top-dressed with the same CRF at a $1.0 \times(71 \mathrm{~g}$ per container) for CTL and a $0.8 \times(57 \mathrm{~g}$ per container) for stratified treatments, placed on respective irrigation zones within the simulated nursery pad, then the project was reinitiated at the two irrigation rates. Growth indices and substrate fertility assessment continued throughout the spring flush. On $341 \mathrm{DAI}$, all remaining plants were photographed and subjective root and shoot quality ratings were assigned with a subjective 1-5 scale (with 5 describing superior plant material). Similar to the initial harvest, foliar samples were collected on all replicates and roots were separated from shoots, dried, and weighed. Dry mass measurements of the shoots included shoot dry mass, dry mass of foliar samples, and dry mass of the clippings taken at 125 DAI.

\subsection{Data Analysis}

Data in tables relating to physical substrate properties were subjected to analysis of variance (ANOVA) or multivariate ANOVA in JMP Pro (15.0, SAS Institute; Cary, NC, USA), while means were separated where appropriate using Tukey's honestly significant difference with $\alpha=0.05$.

Substrate treatments were placed in a completely randomized design under two irrigation treatments. Analysis of variance (ANOVA) was used to determine the significance of substrate treatment on plant growth parameters within each irrigation treatment via JMP Pro 15 (SAS Institute, Cary, NC, USA). Means were separated using Tukey's HSD when appropriate $(\alpha=0.05)$.

\section{Results and Discussion}

\subsection{Substrate Hydrophysical Properties}

All three substrates utilized as top strata fell within the recommended AS (0.10 to $\left.0.30 \mathrm{~cm}^{3} \mathrm{~cm}^{-3}\right)$ and CC $\left(0.45\right.$ to $\left.0.65 \mathrm{~cm}^{3} \mathrm{~cm}^{-3}\right)$ ranges given by Bilderback et al. [30] (Table 1). The coarse substrate utilized as the bottom strata in the stratified treatments 
had higher AS and lower CC values than the other substrates used, as it was specifically engineered to drain more readily than the CTL. The coarseness of the bark was chosen to significantly improve drainage and gas exchange and to reduce water holding in the lower strata, as coarse components increase air space, improve drainage as a result [31]. While the AS and CC values differed between bark textures, the TP value of the conventional bark was equivalent to bark fines $(>6.3 \mathrm{~mm})$ and coarse bark $(>12.6 \mathrm{~mm})$. This has been shown to be a common occurrence with substrate materials, as changing particle size tends to shift the AS/CC ratio while having little effect on TP [23]. This follows a basic principle of geometry that states that a group of uniform spheres will always occupy $66.7 \%$ of a cylindrical container, regardless of the sphere size [32]. As such, changing the particle diameter should have a negligible effect on TP; however, the inclusion of peat did reduce TP within the substrate when compared to the coarse bark (Table 1), which was likely a result of the fibrous nature and rectangular geometry of the peat. The conventional pine bark was very similar to the aged bark substrates used in previous bark assessments [33].

Table 1. Physical characteristics of the four substrate components used to design the control and stratified substrates as determined by using a porometer and sieving dry material.

\begin{tabular}{|c|c|c|c|c|c|c|c|}
\hline \multirow[b]{2}{*}{ Substrate } & \multirow[b]{2}{*}{$\begin{array}{l}\text { Container } \\
\text { Capacity } \\
\mathrm{cm}^{3} \mathrm{~cm}^{-3}\end{array}$} & \multirow[b]{2}{*}{$\begin{array}{l}\text { Air Space } \\
\mathrm{cm}^{3} \mathrm{~cm}^{-3}\end{array}$} & \multirow[b]{2}{*}{$\begin{array}{c}\text { Total } \\
\text { Porosity } \\
\mathrm{cm}^{3} \mathrm{~cm}^{-3}\end{array}$} & \multicolumn{4}{|c|}{ Particle Size Distribution } \\
\hline & & & & $\begin{array}{c}\text { Bulk } \\
\text { Density } \\
\mathrm{g} \mathrm{cm}^{-3} \\
\end{array}$ & $\begin{array}{c}\text { Large } \\
>2.0 \mathrm{~mm} \\
\mathrm{~g} \mathrm{~g}^{-1}\end{array}$ & $\begin{array}{c}\text { Medium } \\
2.0-0.7 \mathrm{~mm} \\
\mathrm{~g} \mathrm{~g}^{-1}\end{array}$ & $\begin{array}{c}\text { Fines } \\
<0.7 \mathrm{~mm} \\
\mathrm{~g} \mathrm{~g}^{-1}\end{array}$ \\
\hline $\begin{array}{l}\text { Conventional } \\
\text { bark }(\leq 16 \mathrm{~mm})\end{array}$ & $0.51 b^{x}$ & $0.27 \mathrm{~b}$ & $0.78 \mathrm{ab}$ & $0.21 \mathrm{a}$ & $0.64 \mathrm{~b}$ & $0.19 \mathrm{~b}$ & $0.17 \mathrm{c}$ \\
\hline $\begin{array}{l}\text { Conventional } \\
\text { bark-peat }\end{array}$ & $0.62 \mathrm{a}$ & $0.12 \mathrm{~d}$ & $0.75 \mathrm{~b}$ & $0.19 \mathrm{a}$ & $0.45 \mathrm{c}$ & $0.21 \mathrm{~b}$ & $0.34 \mathrm{a}$ \\
\hline $\begin{array}{l}\text { Bark fines } \\
(\leq 6.3 \mathrm{~mm})\end{array}$ & $0.59 \mathrm{a}$ & $0.19 \mathrm{c}$ & $0.79 \mathrm{ab}$ & $0.17 \mathrm{~b}$ & $0.41 \mathrm{c}$ & $0.34 \mathrm{a}$ & $0.25 \mathrm{~b}$ \\
\hline $\begin{array}{l}\text { Coarse bark } \\
(>12.6 \mathrm{~mm})\end{array}$ & $0.37 \mathrm{c}$ & $0.44 \mathrm{a}$ & $0.81 \mathrm{a}$ & $0.14 \mathrm{c}$ & $0.76 \mathrm{a}$ & $0.12 \mathrm{c}$ & $0.12 \mathrm{c}$ \\
\hline$p$-value & $<0.0001$ & $<0.0001$ & 0.0079 & $<0.0001$ & $<0.0001$ & $<0.0001$ & 0.0002 \\
\hline
\end{tabular}

All substrates contained between $41 \%$ and $76 \%$ large particles $(>2.0 \mathrm{~mm})$, which represented the predominant texture class for all substrates (Table 1). Aside from being spatially dominated by large sized particles, there were few similarities in particle size distribution among the four substrates. The bark-peat and bark fines possessed equivalent amounts of large particles but varied in proportions of medium particles and fines $(0.21$ and $0.34 \mathrm{~g} \mathrm{~g}^{-1}$ for the bark-peat and 0.34 and $0.25 \mathrm{~g} \mathrm{~g}^{-1}$ in the bark fines). Consequently, the bark fines had higher AS than the bark-peat.

The MCC data were fit to a Brooks and Corey [27] hydraulic model (Figure 1, Table 2) and hydraulic properties $\theta r, h_{b}$, and $\lambda$ were computed. The models all fit very strongly to the data, with $\mathrm{R}^{2}>0.95$ for all four substrates. The two screened barks (coarse and fines) had higher modeled $\theta \mathrm{r}$ (residual water content indicates where decreases in substrate water potential no longer reduce VWC; Stephens and Rehfeldt [34]) compared to the substrates without screening (conventional and bark-peat). This model effect is a result of the continued reduction of VWC, as substrate water potential was reduced further than in the bark-peat mixture and the conventional bark, in which the data began to develop a more asymptotic relationship. Moreover, $\lambda$ values (indicative of pore uniformity) were greater for the two screened bark substrates. This increased uniformity can be observed in the steep decline in VWC between 0 and $-50 \mathrm{hPa}$ for the coarse and fine barks. This uniformity is a result of the screening process, which creates a more uniform pore size distribution in the bark substrates [12]. The inclusion of peat moss increased the pore size distribution slightly, although not to the same degree as screening. The more gradual 
reductions of VWC between 0 and $-50 \mathrm{hPa}$ in the conventional and the bark-peat indicate the more heterogeneous distribution of pore sizes (Figure 1$)$. The increases of $h_{b}(k n o w n$ as the bubbling point or air entry value) in the bark-peat and the bark fines were likely due to these substrates having smaller overall pores as a result of a shift to the finer particles (Table 1). The bubbling point is indicative of the tension where gravitational drainage first initiates and air enters the substrate matrix (i.e., the air entry value).

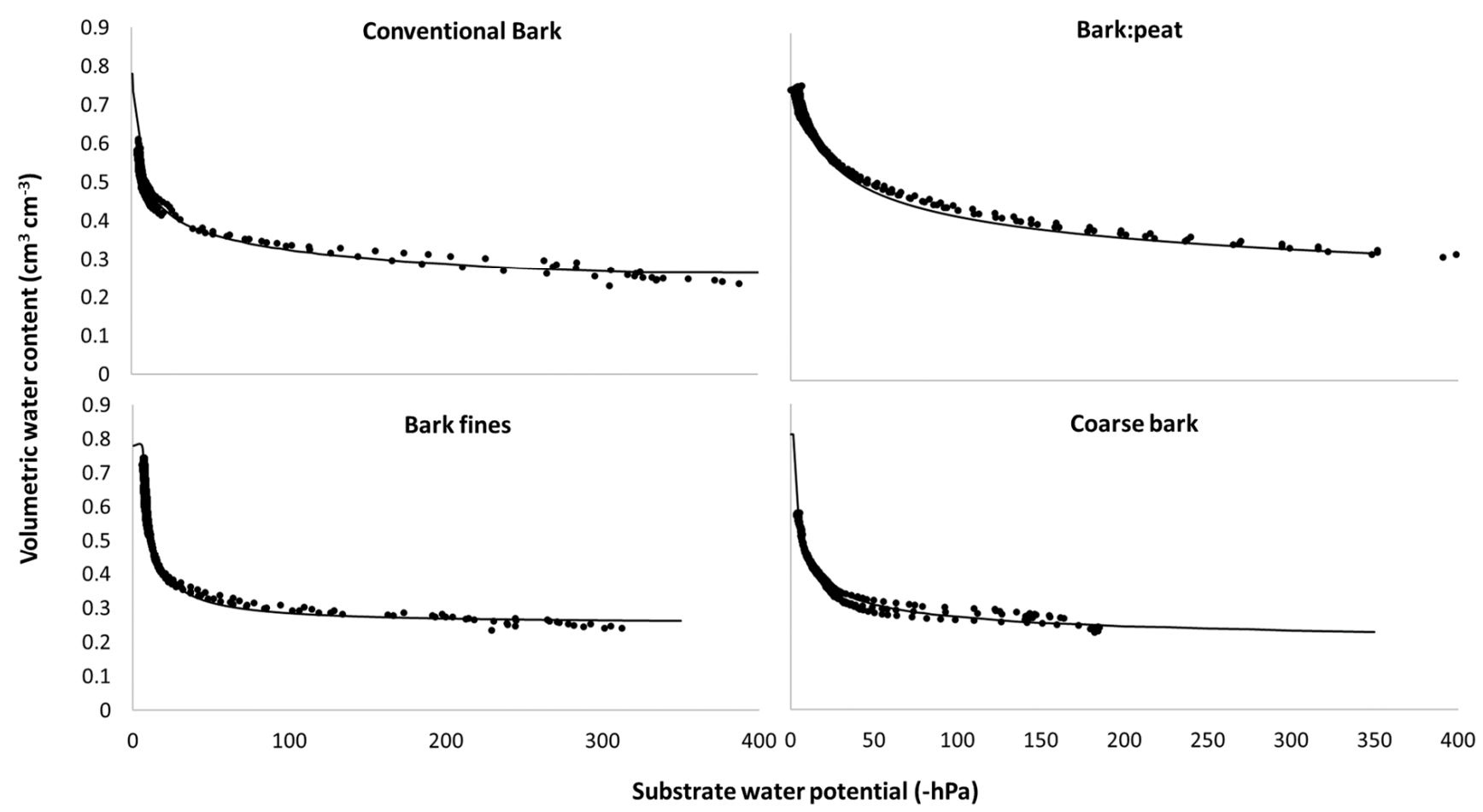

Figure 1. Moisture characteristic curves for the four components used in the control and stratified substrates as determined by evaporative method. The relationship between substrate water potential and volumetric water content measures (circles) were used to fit to a Brooks and Corey [27] hydraulic model (lines).

Table 2. Hydraulic properties and parameters of four bark-based soilless substrates engineered through particle fractionation or amendment with fibrous materials. Properties and parameters were derived from moisture characteristic curves fit to the Brooks and Corey [27] hydraulic model.

\begin{tabular}{|c|c|c|c|c|c|c|c|c|}
\hline \multirow[b]{2}{*}{ Substrate } & \multicolumn{3}{|c|}{ Substrate Hydraulic Properties } & \multicolumn{3}{|c|}{ Hydraulic Model Parameters ${ }^{z}$} & \multicolumn{2}{|c|}{ Model Statistics } \\
\hline & $\begin{array}{l}\text { EAW y } \\
\% \text { vol. }\end{array}$ & $\begin{array}{l}\text { WBC }^{x} \\
\% \text { vol. }\end{array}$ & $\begin{array}{l}\text { AW w } \\
\% \text { vol. }\end{array}$ & $\begin{array}{c}\theta \mathrm{r} \\
\mathrm{cm}^{3} \mathrm{~cm}^{-3}\end{array}$ & $\begin{array}{l}\mathrm{h}_{\mathrm{b}} \\
\mathrm{cm}\end{array}$ & $\lambda$ & $\mathbf{R}^{2}$ & $\operatorname{AIC}^{v}$ \\
\hline Conventional bark & 12.1 & 4.2 & 34.9 & 1.48 & 0.72 & 0.18 & 0.9597 & 322.02 \\
\hline Bark-peat & 18.8 & 6.4 & 52.3 & 0.01 & 6.10 & 0.20 & 0.9847 & 456.63 \\
\hline Bark fines & 24.5 & 3.1 & 30.7 & 25.34 & 5.69 & 0.99 & 0.9550 & 703.53 \\
\hline Coarse bark & 14.3 & 3.7 & 27.21 & 16.82 & 1.54 & 0.44 & 0.9806 & 258.97 \\
\hline
\end{tabular}

${ }^{\mathrm{z}}$ Parameters used to fit data to the Brooks and Corey [27] hydraulic model. y Easily available water is water held between -10 and $-50 \mathrm{hPa}$. ${ }^{\mathrm{x}}$ Water buffering capacity is water held between -50 and $-100 \mathrm{hPa} .{ }^{\mathrm{w}}$ Available water is this research is calculated as the difference in measured container capacity and modeled volumetric water content at $-1.5 \mathrm{MPa} .{ }^{\mathrm{v}}$ Akaike information criterion is an estimator of the predictive error of statistical models.

The bark-peat substrate had the greatest quantity of AW, with over $50 \%$ of the volume of the substrate matrix capable of supplying water to the crop. Past research has shown that fiber substrates often tend to have relatively high hydraulic conductivity when compared to bark-based substrates, and are, therefore, capable of delivering greater proportions of water to crops $[15,35]$. The gradual slope between -10 and $-50 \mathrm{hPa}$ in the bark-peat substrate indicates a more gradual release of water within the EAW range. The bark-peat and bark fines had the greatest EAW and WBC values. Recent studies have shown increased 
proportions of water held within this $-10 \mathrm{hPa}$ to $-100 \mathrm{hPa}$ substrate water potential range to be available to plants from increased proportions of fiber and reductions in particle size for bark materials [12,36].

While the static physical properties of the individual substrates utilized in this research differed, the calculated TP, AS, and CC estimates of the stratified substrates ((upper strata + lower strata)/2) were similar, especially regarding $\mathrm{TP}$, which was $0.78 \mathrm{~cm}^{3} \mathrm{~cm}^{-3}$ for CTL. The calculated TP estimate for the SF $\left(0.80 \mathrm{~cm}^{3} \mathrm{~cm}^{-3}\right), \mathrm{SC}\left(0.80 \mathrm{~cm}^{3} \mathrm{~cm}^{-3}\right)$, and SP $\left(0.78 \mathrm{~cm}^{3} \mathrm{~cm}^{-3}\right)$ were all within $0.02 \mathrm{~cm}^{3} \mathrm{~cm}^{-3}$. Similar to the four individual bark substrates (Table 1), the TP remained relatively constant as the bark particle size was adjusted, while there were differences in the AS/CC ratio. The calculated AS and CC estimates of stratified substrates were roughly equivalent, with the SP being the most similar (CC of $0.50 \mathrm{~cm}^{3} \mathrm{~cm}^{-3}$ and AS of $0.27 \mathrm{~cm}^{3} \mathrm{~cm}^{-3}$ ). The pooled AS values for SC and SF were within 0.07 and $0.03 \mathrm{~cm}^{3} \mathrm{~cm}^{-3}$, while the estimated $C C$ values were within 0.07 and $0.05 \mathrm{~cm}^{3} \mathrm{~cm}^{-3}$. The stratification process redistributed the water and air holding capacity levels within the container by increasing the AS in the lower strata (the coarse bark had increased AS) and increasing the CC in the upper strata (the bark fines and bark-peat had the greatest CC; Table 1). In a traditional homogeneous container system, gravitational forces cause a moisture gradient from the top of the container to the bottom, resulting in increased air space in the upper portion of the container and increased water retention in the lower portions of the container. Through stratification, we redesigned static physical properties to invert this process (without considering gravitational forces).

\subsection{Initial Growth}

Plants in SP outgrew all other substrate treatments within the first 40 DAI under normal irrigation (Figure 2). By 63 DAI, the GI levels of all plants grown in stratified substrates had surpassed the CTL under normal irrigation. The substrate treatment significantly affected the GI levels of plants on 63 DAI ( $p=0.0570), 83$ DAI $(p=0.0065), 107$ DAI $(p=0.0413)$, and $125 \mathrm{DAI}(p=0.0084)$ under normal irrigation, with stratified substrates producing larger plants than the CTL at all dates. The initial growth occurred primarily in the upper strata, showing equal (SC) or finer (SF and SP) particle texture levels than the CTL. The increased early growth indicates that the fine particles were not deleterious to plant growth, while the increased fertilizer rate in the growing region likely supported additional growth. Substrates primarily comprised of fine particles tend to have low AS, which has been shown to result in oxygen deficiency [37]. Stratifying the system with coarse particles layered below fine particles alters the hydraulic distribution to reduce excessive water retention, which can cause deleteriously low air-filled porosities within the container; thus, the benefits of using fine-textured substrates (increased pore uniformity, moisture distribution, and nutrient retention) were provided to growing crops without restricting drainage, a common phenomenon associated with utilizing fine-textured mineral soils in containers [38].

There were no detectable differences in the ratios of dry mass between roots and shoots $(\mathrm{R} / \mathrm{S})$ among substrate treatments in the normally irrigated plants at initial harvest $(p=0.2818)$. Neither root dry mass $(p=0.2373)$ nor shoot dry mass $(p=0.2980)$ was affected by substrate treatment under normal irrigation (16 $\mathrm{mm}$ day 1$)$, with equal plant growth resulting from reduced fertilizer rates in stratified substrates. The stratification process allowed similar or superior quality crops to be produced with $20 \%$ less fertilizer (Figure 3 ). Moreover, the plants grown in the stratified substrates grew wider (Figure 3) and were more visually appealing (Figure 4) than those grown in CTL due to increased blooms and greater spread. 


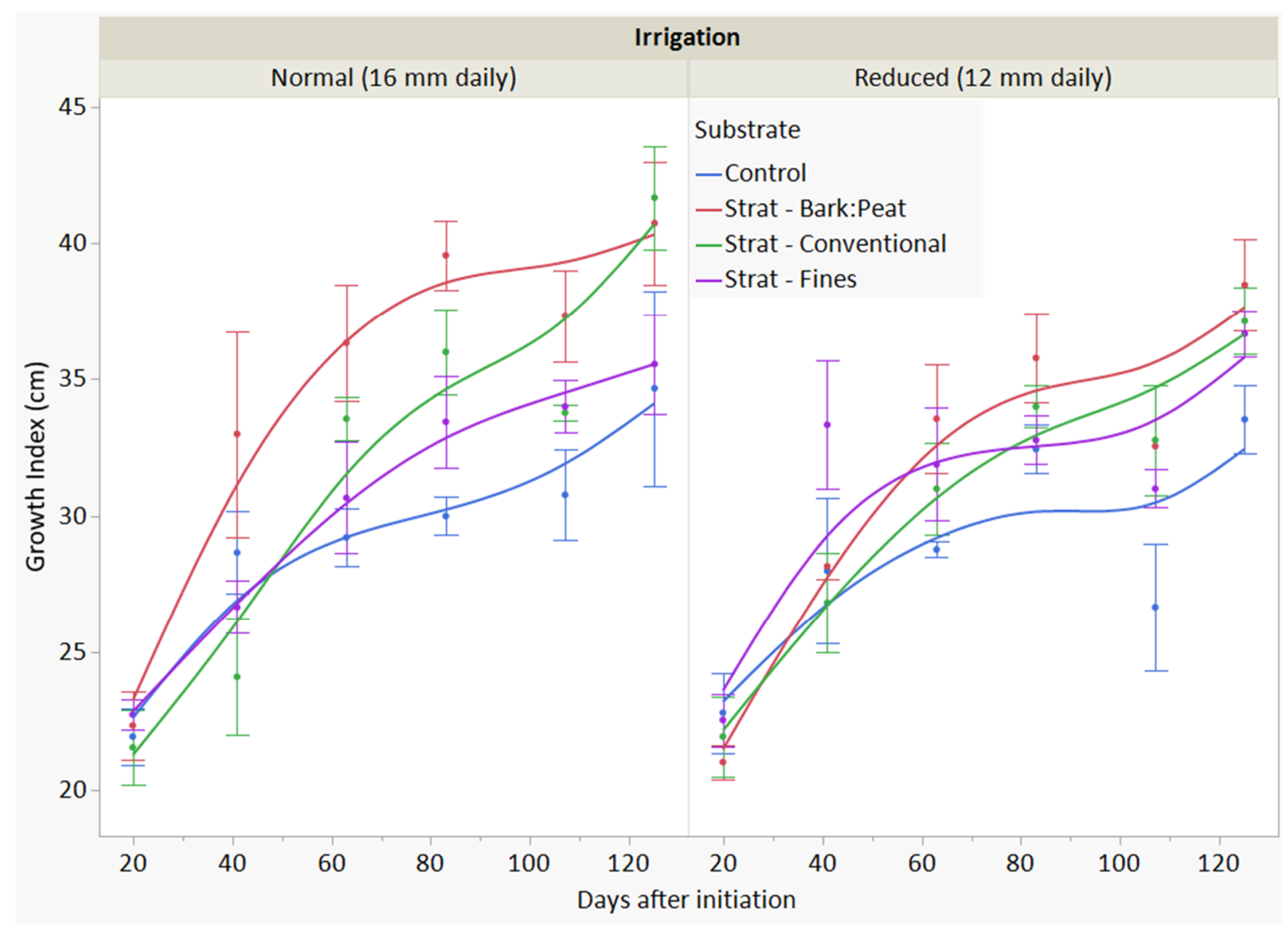

Figure 2. The changes in growth index for Drift roses planted in a conventional pine bark substrate (control) or stratified substrates, in which either conventional pine bark substrate amended with 35\% peat (by vol.; bark-peat), conventional pine bark (conventional), or fine pine bark (fines) was layered on top of coarse screened pine bark. Plants were irrigated with $16 \mathrm{~mm}$ (normal; control) or $12 \mathrm{~mm}$ of water daily (reduced). Measures reported from 0 to 125 days after initiation. Bars represent standard errors from the mean.

The growth index values for plants produced with reduced irrigation were less influenced by substrate treatment over the growing season than those with normal irrigation (Figure 2), with no differences in substrate treatment at the time of harvest (125 DAI; $p=0.0832$ ). While there were no detectable differences in crop GI among the substrate treatments, the CTL numerically had the lowest GI at 63 DAI and beyond (Figure 2). Among the plants in the three stratified substrates, those grown in SF had numerically reduced GI when compared to plants grown in SP and SC during the first 125 DAI (Figure 2). There were no differences in root dry mass with any of the substrate treatments under reduced irrigation $(p=0.9936)$.

\subsection{Final Harvest}

After 280 DAI, the plants were put back on the simulated nursery pad. Plants in the control substrate had grown more than those in the stratified substrates, as they overwintered ( $p=0.0758$ on 226 DAI). By 310 DAI, there were no detectable differences in growth among the substrate treatments under normal irrigation $(p=0.4739)$ or reduced irrigation $(p=0.0889)$, and these similarities in GI continued throughout the duration of the study (Figure 5). 


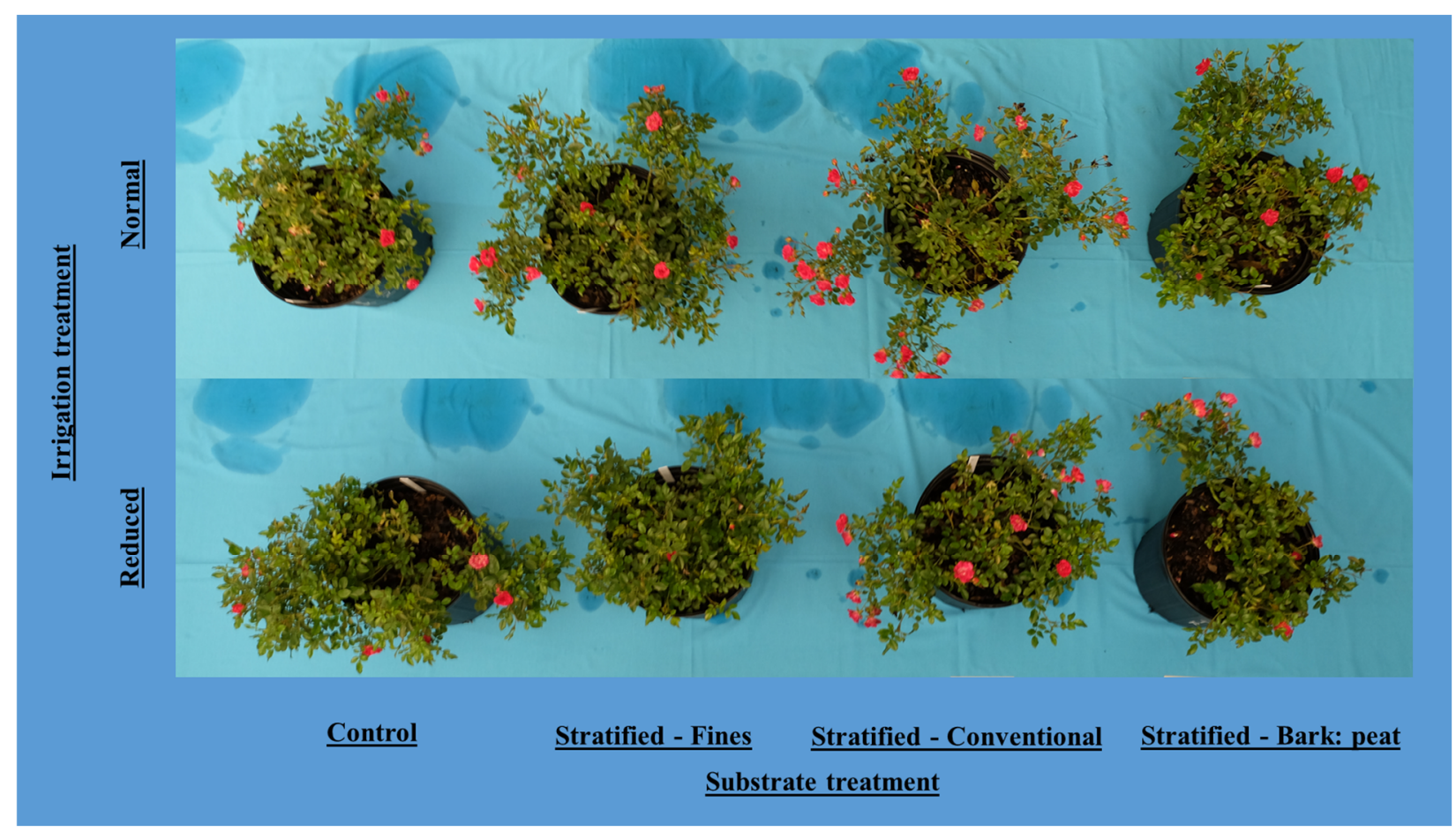

Figure 3. Top view of Drift roses 125 days after initiation. Roses were grown utilizing either a conventional pine bark substrate (control) or stratified substrates, in which either conventional pine bark substrate amended with 35\% peat (by vol.; bark-peat), conventional pine bark (conventional), or fine pine bark (fines) was layered on top of coarse screened pine bark. Plants were irrigated with $16 \mathrm{~mm}$ (normal; control) or $12 \mathrm{~mm}$ of water daily (reduced).

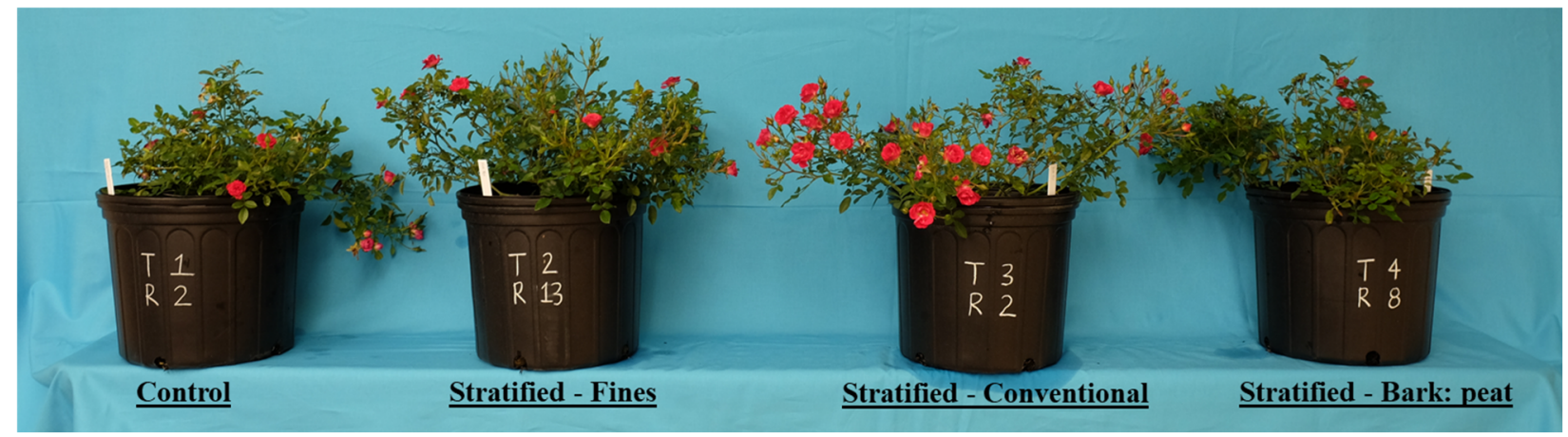

Figure 4. Side view of Drift roses 125 days after initiation. Roses were grown by utilizing either a conventional pine bark substrate (control) or stratified substrates, in which either conventional pine bark substrate amended with 35\% peat (by vol.; bark-peat), conventional pine bark (conventional), or fine pine bark (fines) was layered on top of a coarse screened pine bark. Plants were irrigated with $16 \mathrm{~mm}$ daily.

Similar to the initial harvest, the R/S ratio was unaffected by substrate treatment under normal ( $p=0.8614)$ and reduced irrigation $(p=0.2059)$; however, roses grown in SP and SF numerically had the greatest shoot dry weight values while control plants had the lowest shoot dry weight values in both irrigation groups. The shoot dry weight values of the plants that received reduced irrigation were reduced by $4 \mathrm{~g}$ when compared to those grown under normal irrigation. Moreover, while no detectible differences were observed; the plants grown in stratified substrates tended to have increased proportional root growth after the second growing season.

Before the second growing season, roots in all treatments had explored the entire container and were considered well-established. Subjective root and shoot quality ratings were assessed, and no differences were found among shoots $(p=0.6150)$ and roots $(p=0.1361)$ 
under normal irrigation nor among shoots $(p=0.2906)$ and roots $(p=0.4680)$ under reduced irrigation; thus, stratified substrates were able to outperform CTL treatments during establishment and showed similar growth over long-term production, ultimately producing similar sized plants with a $20 \%$ reduction in fertilizer.

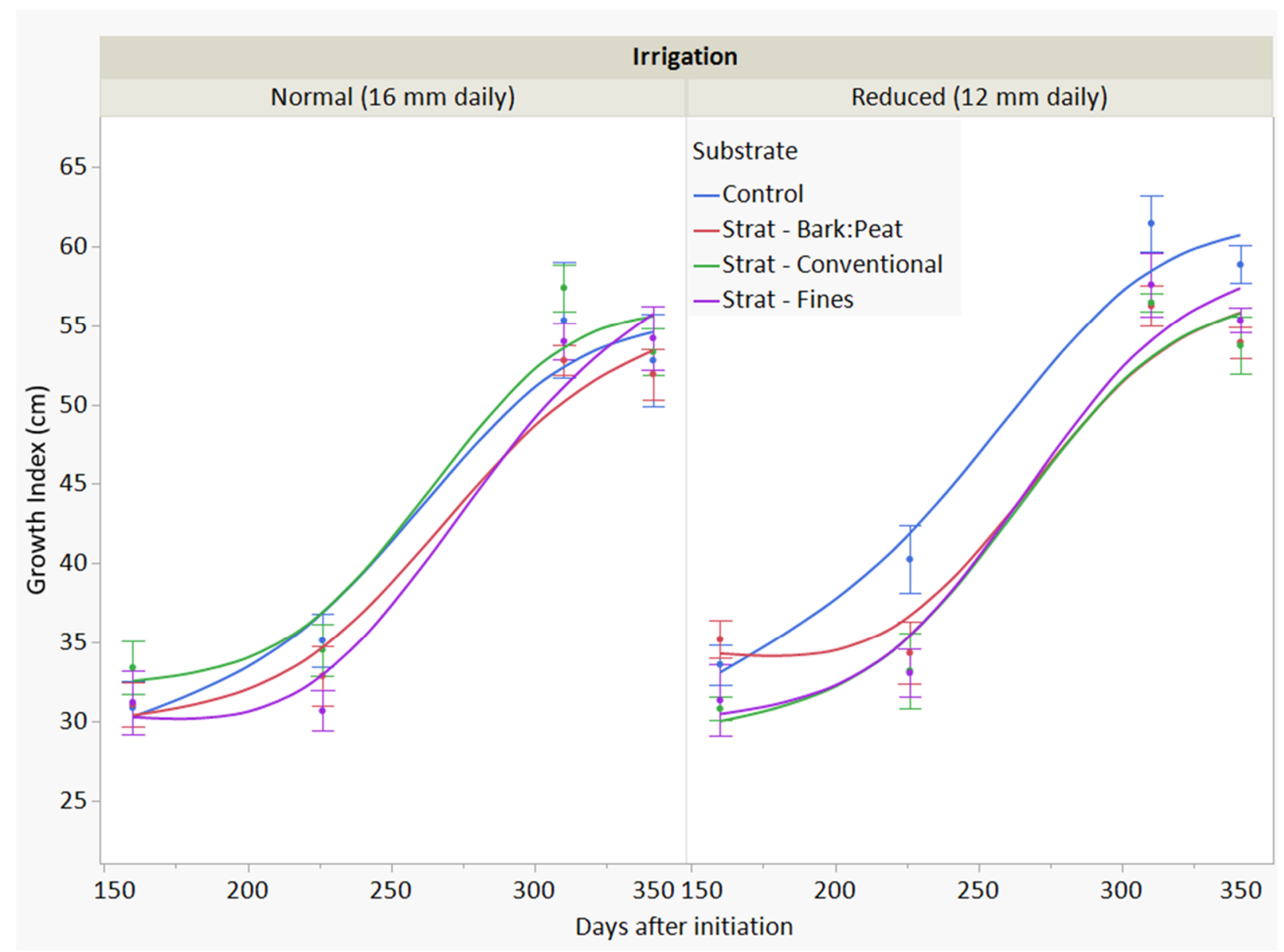

Figure 5. The change in growth index during the spring flush for Drift roses planted in a conventional pine bark substrate (control) or stratified substrates, in which either conventional pine bark substrate amended with 35\% peat (by vol.; barkpeat), conventional pine bark (conventional), or fine pine bark (fines) was layered on top of coarse screened pine bark. Plants were irrigated with $16 \mathrm{~mm}$ (normal; control) or $12 \mathrm{~mm}$ of water daily (reduced). Measures reported from 160 to 340 days after initiation. Bars represent standard errors from the mean.

\subsection{Substrate Fertility}

During the initial growth period, the CTL had lower $\mathrm{pH}$ and higher EC compared to stratified substrates under both normal and reduced irrigation (Figure 6). Under normal irrigation, by $41 \mathrm{DAI}$, the EC from the CTL was more than $3 \times$ greater than from any of the stratified substrates $(p=0.0052)$; however, the measured EC of the CTL was in the recommended range $(\sim 2.0-3.0 \mathrm{mS} / \mathrm{cm})$ for rose crops [39]. This trend continued until 107 DAI, when the EC differential was reduced and all treatments in the normal irrigation group had equivalent pore water EC values (Figure 6).

Electrical conductivity in the reduced irrigation plants followed a similar trend to those under normal irrigation, whereby CTL showed reduced $\mathrm{pH}$ and increased EC when compared all stratified substrates. Similarly, the EC of the control CTL was three-fold greater in the first $83 \mathrm{DAI}$ when compared to the stratified substrates. The pore water $\mathrm{pH}$ was approximately 1.0 unit lower in CTL than the stratified treatments up until 83 DAI and remained lower throughout the initial growth phase (Figure 6). 


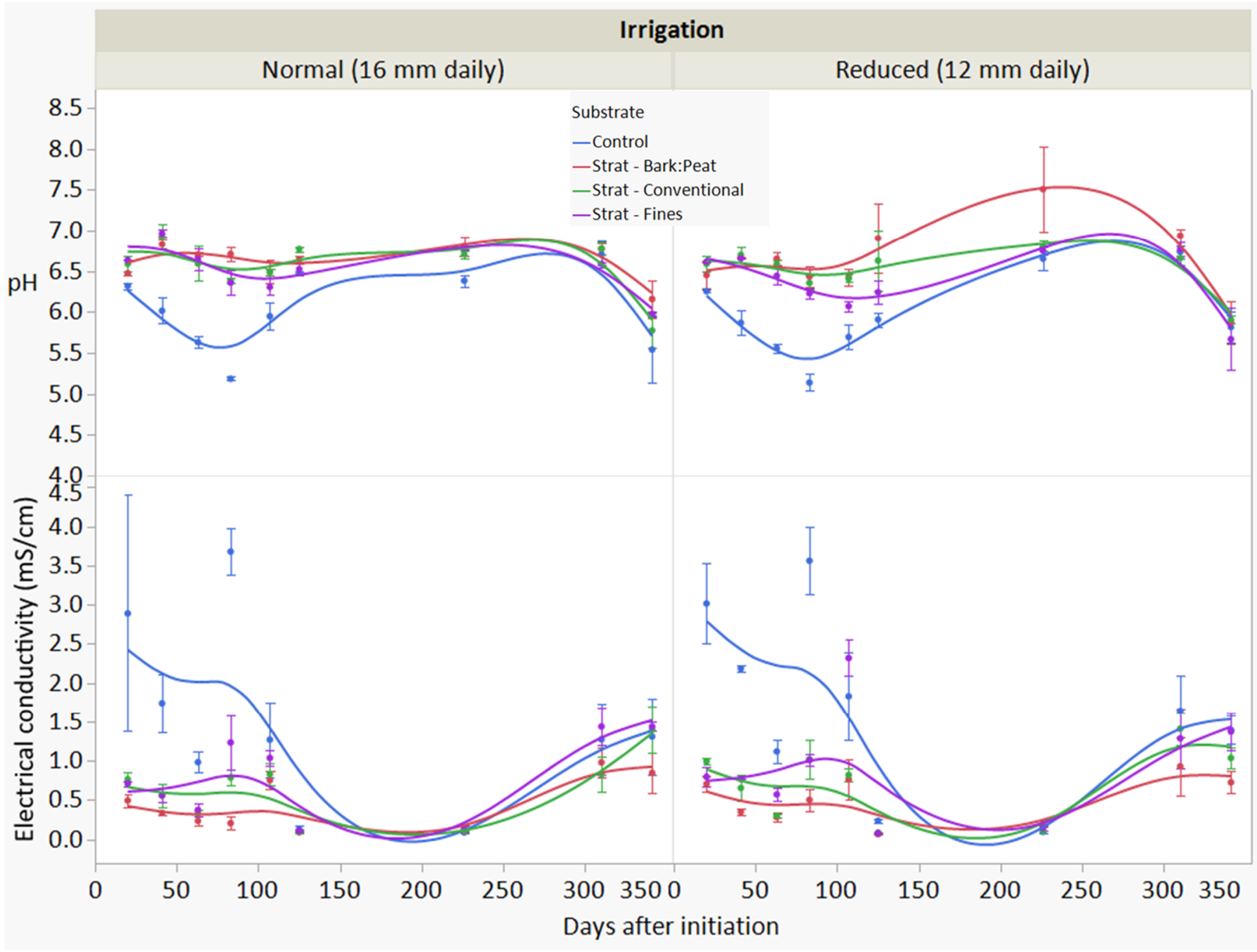

Figure 6. Pore water fertility assessed via pour-through analysis of Drift roses planted in a conventional pine bark substrate (control) or stratified substrates, in which either conventional pine bark substrate amended with 35\% peat (by vol.; barkpeat), conventional pine bark (conventional), or fine pine bark (fines) was layered on top of a coarse screened pine bark. Plants were irrigated with $16 \mathrm{~mm}$ (normal; control) or $12 \mathrm{~mm}$ of water daily (reduced). Bars represent on standard error from the mean.

Differences in EC were expected, as the stratified treatments had 20\% less fertilizer; however, the scale of the observed differences was higher than expected. With an over three-fold increase in pore water EC in the CTL, placement of the fertilizer was most likely responsible for the difference. Nutrients from the fertilizer in the stratified substrates are likely retained more in the upper strata and crops are able to access a greater proportion of the fertilizer before it is leached. With very similar levels of crop growth and quality (Figure 4) and greatly reduced pore water EC values in the stratified treatments, it is likely that the stratified substrates allow for more efficient crop use of fertilizer.

The increased $\mathrm{pH}$ was likely a result of the expected differences in surface area between the different substrates. While not measured specifically in this study, an increased proportion of fine particles will increase the surface area of a substrate [17]. The stratified substrates have increased fines in the upper strata compared to the lower strata. The lime rate was not adjusted for particle size or potential surface area, meaning the lower strata received the same lime rate as the upper strata. This likely increased the $\mathrm{pH}$ in the lower strata more than that of the upper strata. This increased lime activity in the lower strata was likely the driver for the increased pore water $\mathrm{pH}$; however, the $\mathrm{SC}$ treatment had the same substrate in the upper strata as the CTL and the $\mathrm{pH}$ of SC was similar to that of the 
other stratified treatments throughout the study. The pour-through process used to extract the pore water may be biased towards pore water in the lower strata, especially when considering the displacement theory, wherein all water that is forced out of the bottom is pore water displaced by in introduction of the deionized water.

There were no differences in pore water $\mathrm{pH}$ or EC during the spring flush (Figure 6). The replicates were top-dressed with CRF (stratified treatments received $80 \%$ rate of the control) before being replaced in production. The similar EC values after top-dressing are evidence that the fertilizer incorporated throughout the substrate in the initial phase of the experiment was responsible for the higher EC observed then.

\subsection{Foliar Nutrition}

Foliar concentrations of N, P, S, and Ca were affected by the substrate at 125 DAI (initial harvest), regardless of the daily irrigation amount (Table 3). Foliar $\mathrm{N}$ concentrations, regardless of the irrigation rate, were greatest in the CTL. The higher foliar N in roses was a result of increased solutes in substrate pore water, as observed in the higher pour-through EC values at 20 to $107 \mathrm{DAI}$; however, there was no effect on shoot or root mass, indicating it was luxury consumption or excess uptake over what was needed for growth. Phosphorus, $\mathrm{S}$, and Ca showed similar trends in luxury consumption; however, concentrations varied across substrate treatments. Nearly all of the assessed foliar concentrations were within the recommended ranges described by Hermida et al. [40], except for $\mathrm{Ca}$ and $\mathrm{Mg}$, which were under the optimal thresholds of $1.0 \%$ and $0.25 \%$, respectively.

Table 3. Mineral nutrient concentrations in recently matured leaves of Red Drift roses at 125 days (initial harvest) and 341 days (final harvest) when being produced in a conventional pine bark substrate (control) or stratified substrates, in which either conventional pine bark substrate amended with 35\% peat (by vol.; bark-peat), conventional pine bark (conventional), or fine pine bark (fines) was layered on top of a coarse screened pine bark. Plants were irrigated with $16 \mathrm{~mm}$ (normal; control) or $12 \mathrm{~mm}$ of water daily (reduced).

\begin{tabular}{|c|c|c|c|c|c|c|c|c|}
\hline Irrigation Rate & Substrate & $\%^{\mathrm{z}} \mathrm{N}$ & $\% \mathbf{P}$ & $\% \mathrm{~K}$ & $\% \mathrm{~S}$ & $\% \mathrm{Ca}$ & $\% \mathbf{M g}$ & Fe (ppm) \\
\hline & \multicolumn{8}{|c|}{ Initial Harvest } \\
\hline $16 \mathrm{~mm} /$ day & Control & $3.71 \mathrm{a}^{\mathrm{y}}$ & $0.39 \mathrm{a}$ & 1.89 & $0.29 \mathrm{a}$ & $0.94 \mathrm{a}$ & 0.19 & 120.2 \\
\hline \multirow[t]{4}{*}{ Normal } & Stratified-Bark-peat & $3.11 \mathrm{~b}$ & $0.27 \mathrm{c}$ & 1.49 & $0.22 \mathrm{~b}$ & $0.72 \mathrm{~b}$ & 0.15 & 155.9 \\
\hline & Stratified-Conventional & $3.03 \mathrm{~b}$ & $0.32 \mathrm{bc}$ & 1.61 & $0.23 \mathrm{~b}$ & $0.77 \mathrm{~b}$ & 0.16 & 140.3 \\
\hline & Stratified-Fines & $3.27 \mathrm{~b}$ & $0.33 \mathrm{~b}$ & 1.67 & $0.26 \mathrm{ab}$ & $0.77 \mathrm{~b}$ & 0.16 & 153.1 \\
\hline & $p$-value & 0.0044 & 0.0018 & 0.1914 & 0.0035 & 0.0017 & 0.4826 & 0.5032 \\
\hline $12 \mathrm{~mm} /$ day & Control & $3.93 \mathrm{a}$ & $0.40 \mathrm{a}$ & 1.85 & $0.29 \mathrm{a}$ & $0.86 \mathrm{a}$ & $0.23 \mathrm{a}$ & 130.2 \\
\hline \multirow{5}{*}{ Reduced } & Stratified-Bark-peat & $3.22 \mathrm{~b}$ & $0.31 \mathrm{~b}$ & 1.81 & $0.24 \mathrm{c}$ & $0.70 \mathrm{~b}$ & $0.18 \mathrm{~b}$ & 130.8 \\
\hline & Stratified-Conventional & $3.52 \mathrm{~b}$ & $0.36 \mathrm{a}$ & 1.66 & $0.26 \mathrm{~b}$ & $0.80 \mathrm{ab}$ & $0.16 \mathrm{~b}$ & 148.2 \\
\hline & Stratified-Fines & $3.50 \mathrm{~b}$ & $0.35 \mathrm{ab}$ & 1.73 & $0.29 \mathrm{ab}$ & $0.90 \mathrm{a}$ & $0.18 \mathrm{~b}$ & 153.9 \\
\hline & $p$-value & 0.0046 & 0.0080 & 0.6311 & 0.0010 & 0.0138 & 0.0266 & 0.2898 \\
\hline & \multicolumn{8}{|c|}{ Final Harvest } \\
\hline $16 \mathrm{~mm} /$ day & Control & 2.87 & 0.25 & $2.07 \mathrm{~b}$ & 0.29 & 1.30 & 0.13 & 137.0 \\
\hline \multirow[t]{4}{*}{ Normal } & Stratified-Bark-peat & 2.80 & 0.21 & $2.42 \mathrm{a}$ & 0.28 & 1.11 & 0.10 & 141.1 \\
\hline & Stratified-Conventional & 2.91 & 0.21 & $2.53 \mathrm{a}$ & 0.30 & 1.32 & 0.09 & 141.5 \\
\hline & Stratified-Fines & 2.87 & 0.25 & $2.37 \mathrm{a}$ & 0.28 & 1.20 & 0.10 & 151.9 \\
\hline & $p$-value & 0.9149 & 0.3497 & 0.0266 & 0.8779 & 0.0591 & 0.2568 & 0.9100 \\
\hline $12 \mathrm{~mm} /$ day & Control & 2.89 & $0.25 \mathrm{a}$ & $2.21 \mathrm{~b}$ & 0.30 & 1.16 & $0.14 \mathrm{a}$ & 153.6 \\
\hline \multirow[t]{4}{*}{ Reduced } & Stratified-Bark-peat & 2.95 & $0.20 \mathrm{~b}$ & $2.89 \mathrm{a}$ & 0.31 & 1.19 & $0.08 \mathrm{v}$ & 130.9 \\
\hline & Stratified-Conventional & 2.76 & $0.20 \mathrm{~b}$ & $2.47 \mathrm{~b}$ & 0.28 & 1.35 & $0.11 \mathrm{~b}$ & 113.6 \\
\hline & Stratified-Fines & 2.80 & $0.25 \mathrm{a}$ & $2.26 \mathrm{~b}$ & 0.31 & 1.22 & $0.12 \mathrm{ab}$ & 117.5 \\
\hline & $p$-value & 0.2795 & 0.0039 & 0.0004 & 0.7656 & 0.1414 & 0.0003 & 0.5428 \\
\hline
\end{tabular}

${ }^{\mathrm{z}}$ Percent of dry mass. ${ }^{\mathrm{y}}$ Means separated with Tukey's honest significant difference (alpha $\left.=0.05\right)$ within individual irrigation and harvest groups when ANOVA assessment indicated substrate effects. Values with the same letter are not considered statistically different. 
At $341 \mathrm{DAI}$, only the foliar $\mathrm{K}$ concentration was affected when receiving $16 \mathrm{~mm}$ irrigation daily. All stratified substrates showed increased K, likely due to K dilution from increased shoot mass growth between 125 and 341 DAI in the CTL substrate. Foliar P, K, and $\mathrm{Mg}$ concentrations varied among substrate treatments, most likely as a result of shoot growth but not mineral nutrient acquisition, since neither the root growth, root-to-shoot ratio, root quality, or substrate pore water $\mathrm{pH}$ and $\mathrm{EC}$ varied across treatments from the time of the initial and final harvest. Foliar concentrations of $\mathrm{Mg}$ were again below the $0.25 \%$ recommend range in all treatments [40]; however, by 341 DAI, foliar Ca concentrations were within the recommended range for all substrate and irrigation treatments.

\section{Conclusions}

Substrate stratification within containers caused no deleterious effects on crop growth or development. Equal crop quality and size were achieved with a $20 \%$ reduction in fertilizer; however, the authors would like to acknowledge that further investigation into reduction of fertilizer is needed, and comparisons to reduced fertilizer in a non-stratified system would be beneficial. Moreover, reduction of daily water did not adversely affect the crops grown in stratified systems when compared to the control. Stratified systems present a considerable opportunity to increase or maintain containerized crop productivity while mitigating resource waste through excessive leaching or application. With the onset of stratified substrates as a potential cultural management strategy for containerized crop producers, further research is needed to provide a roadmap for successfully implementing this strategy in commercial production nurseries. Substrate stratification is a non-conventional practice, with potential for more efficient growth; however, there are concerns associated with the logistics for utilizing multiple substrate materials in a single container (i.e., labor and organization). Prior to implementation, a cost analysis of associated logistics would be needed to identify true returns on investment associated with growing plants in stratified substrates; however, growers have indicated potential ease of adoption with existing technologies, especially in regard to automated container filling with two-hopper systems (personal communications).

Author Contributions: Conceptualization, J.S.F., J.S.O.J., and J.E.A.; formal analysis, J.S.F. and J.S.O.J.; funding acquisition, J.S.F., J.S.O.J., and J.E.A.; investigation, J.S.F. and J.S.O.J.; methodology, J.S.F.; project administration, J.S.F.; writing — original draft, J.S.F.; writing—review and editing, J.S.F., J.S.O.J., and J.E.A. All authors have read and agreed to the published version of the manuscript.

Funding: This research was funded in part by the Horticultural Research Institute (award 6005681) and through Hatch fund LAB-94458.

Institutional Review Board Statement: Not applicable.

Informed Consent Statement: Not applicable.

Conflicts of Interest: The authors declare no conflict of interest.

\section{References}

1. Bolques, A.; Knox, G.; Chappell, M.; Landrum, L.; Duke, E. Components of sustainable production practices for container plant nurseries. Proc. Fla. State Hort. Soc. 2011, 124, 294-298.

2. Mathers, H.M.; Case, L.T.; Yeager, T.H. Improving Irrigation Water Use in Container Nurseries. HortTechnology 2005, 15, 8-12. [CrossRef]

3. Fulcher, A.; Fernandez, T. Sustainable nursery irrigation management series: Part I. Water use in nursery production. Univ. Tennessee Bul. 2013, W278, 13-0098.

4. Million, J.; Yeager, T.; Albano, J. Consequences of Excessive Overhead Irrigation on Runoff during Container Production of Sweet Viburnum. J. Environ. Hortic. 2007, 25, 117-125. [CrossRef]

5. Abdi, D.E.; Fernandez, T. Reducing water and pesticide movement in nursery production. HortTechnology 2019, 29, 730-735. [CrossRef]

6. Fulcher, A.; LeBude, A.V.; Owen, J.; White, S.A.; Beeson, R.C. The Next Ten Years: Strategic Vision of Water Resources for Nursery Producers. HortTechnology 2016, 26, 121-132. [CrossRef] 
7. Mack, R.; Owen, J.S.; Niemiera, A.X.; Latimer, J. Virginia Nursery and Greenhouse Grower Survey of Best Management Practices. HortTechnology 2017, 27, 386-392. [CrossRef]

8. Caplan, S.; Tilt, B.; Hoheisel, G.; Baugher, T.A. Specialty Crop Growers' Perspectives on Adopting New Technologies. HortTechnology 2014, 24, 81-87. [CrossRef]

9. Bilderback, T.; Riley, E.; Jackson, B.; Kraus, H.; Fonteno, W.; Owen, J.; Altland, J.; Fain, G. Strategies for developing sustainable substrates in nursery crop production. Acta Hortic. 2013, 1013, 43-56. [CrossRef]

10. Barrett, G.E.; Alexander, P.D.; Robinson, J.S.; Bragg, N.C. Achieving environmentally sustainable growing media for soilless plant cultivation systems-A review. Sci. Hortic. 2016, 212, 220-234. [CrossRef]

11. Stewart, C.; Marble, S.; Pearson, B.J.; Wilson, P. Impact of Container Nursery Production Practices on Weed Growth and Herbicide Performance. HortScience 2017, 52, 1593-1600. [CrossRef]

12. Fields, J.S.; Owen, J.; Altland, J.E.; van Iersel, M.; Jackson, B.E. Soilless Substrate Hydrology Can Be Engineered to Influence Plant Water Status for an Ornamental Containerized Crop Grown within Optimal Water Potentials. J. Am. Soc. Hortic. Sci. 2018, 143, 268-281. [CrossRef]

13. Jahromi, N.B.; Walker, F.; Fulcher, A.; Altland, J.; Wright, W.C. Growth Response, Mineral Nutrition, and Water Utilization of Container-grown Woody Ornamentals Grown in Biochar-amended Pine Bark. HortScience 2018, 53, 347-353. [CrossRef]

14. Leiva, J.A.; Wilson, P.C.; Albano, J.P.; Nkedi-Kizza, P.; O'Connor, G.A. Pesticide Sorption to Soilless Media Components Used for Ornamental Plant Production and Aluminum Water Treatment Residuals. ACS Omega 2019, 4, 17782-17790. [CrossRef] [PubMed]

15. Fields, J.S.; Owen, J.S., Jr.; Scoggins, H. The influence of substrate hydraulic conductivity of an ornamental container crop grown in suboptimal substrate water potentials. HortScience 2017, 52, 1419-1428. [CrossRef]

16. Fields, J.S.; Owen, J.S., Jr.; Altland, J.E. Stratified substrates: A media management strategy for increased resource efficiency. HortScience 2020, 55, S399-S400.

17. Brady, N.; Weil, R. The Nature and Properties of Soils, 12th ed.; Prentice Hall: Upper Saddle River, NJ, USA, 1996.

18. Riley, E.; Kraus, H.T.; Bilderback, T.E.; Owen, J.S., Jr.; Hunt, W.F. Impact of engineered filter bed substrate composition and plants on stormwater remediation within a rain garden system. J. Environ. Hort. 2018, 36, 30-44.

19. Taylor, D.; Williams, C.; Nelson, S. Water Retention in Root-zone Soil Mixtures of Layered Profiles Used for Sports Turf. HortScience 1997, 32, 82-85. [CrossRef]

20. Chen, X.; Luo, A.C.; Sato, K.; Wakatsuki, T.; Masunaga, T. An introduction of a mulit-soil-layering system: A novel green technology for wastewater treatment in rural areas. Water Environ. J. 2009, 23, 255-262. [CrossRef]

21. Osman, M.; Yusof, K.W.; Takaijudin, H.; Goh, H.W.; Malek, M.A.; Azizan, N.A.; Ghani, A.A.; Abdurrasheed, A.S. A Review of Nitrogen Removal for Urban Stormwater Runoff in Bioretention System. Sustainability 2019, 11, 5415. [CrossRef]

22. Hoskins, T.; Owen, J.S., Jr.; Niemiera, A.X. Controlled-release fertilizer placement affects the leaching pattern of nutrients from nursery containers during irrigation. HortScience 2014, 49, 1341-1345. [CrossRef]

23. Altland, J.E.; Owen, J.S., Jr.; Gabriel, M.Z. Influence of pumice and plant roots on substrate physical properties over time. HortTechnology 2011, 21, 554-557. [CrossRef]

24. Judd, L.A.; Jackson, B.E.; Fonteno, W.C. Rhizometer: An Apparatus to Observe and Measure Root Growth and Its Effect on Container Substrate Physical Properties Over Time. HortScience 2015, 50, 288-294. [CrossRef]

25. Fonteno, W.C.; Harden, C.T. North Carolina State University Horticultural Substrates Lab Manual. 2010. Available online: https://projects.ncsu.edu/project/hortsublab/pdf/porometer_manual.pdf (accessed on 21 May 2021).

26. Fields, J.S.; Owen, J.; Zhang, L.; Fonteno, W.C. Use of the evaporative method for determination of soilless substrate moisture characteristic curves. Sci. Hortic. 2016, 211, 102-109. [CrossRef]

27. Brooks, R.H.; Corey, A.T. Hydraulic Properties of Porous Media; Hydrol. Paper 3; Colorado State University: Fort Collins, CO, USA, 1964.

28. Seki, K. SWRC fit-A nonlinear fitting program with a water retention curve for soils having unimodial and bimodial pore structure. Hydrol. Earth Syst. Sci. Discuss. 2007, 4, 407-437.

29. LeBude, A.V.; Bilderback, T.E. The Pour-Through Extraction Procedure: A Nutrient Management Tool for Nursery Crops; North Carolina Cooperative Extension Service: Raleigh, NC, USA, 2009.

30. Bilderback, T.; Boyer, C.; Chappell, M.; Fain, G.; Fare, D.; Gilliam, C.; Jackson, B.; Lea-Cox, J.; LeBude, A.; Niemiera, A.; et al. Best Management Practices, Guide for Producing Nursery Crops; Southern Nursery Association: Ackworth, GA, USA, 2013.

31. Spomer, A.L. Small soil containers as experimental tools: Soil water relations. Commun. Soil Sci. Plant Anal. 1975, 6, 21-26. [CrossRef]

32. Jury, W.A.; Horton, R. Soil Physics; Wiley: Hoboken, NJ, USA, 2004.

33. Altland, J.E.; Owen, J.; Jackson, B.E.; Fields, J.S. Physical and Hydraulic Properties of Commercial Pine-bark Substrate Products Used in Production of Containerized Crops. HortScience 2018, 53, 1883-1890. [CrossRef]

34. Stephens, D.B.; Rehfeldt, K.R. Evaluation of Closed-Form Analytical Models to Calculate Conductivity in a Fine Sand. Soil Sci. Soc. Am. J. 1985, 49, 12-19. [CrossRef]

35. Caron, J.; Elrick, D.E.; Beeson, R.; Boudreau, J. Defining Critical Capillary Rise Properties for Growing Media in Nurseries. Soil Sci. Soc. Am. J. 2005, 69, 794-806. [CrossRef]

36. Jahromi, N.B.; Fulcher, A.; Walker, F.; Altland, J. Optimizing Substrate Available Water and Coir Amendment Rate in Pine Bark Substrates. Water 2020, 12, 362. [CrossRef] 
37. Nkongolo, N.V.; Caron, J. Bark particle sizes and the modification of the physical properties of peat substrates. Can. J. Soil Sci. 1999, 79, 111-116. [CrossRef]

38. Bilderback, T.E. Container soils and soilless media. P 1-12. In North Carolina Nursery Crops Production Manual; Bul. NCPM 9; Bonaminio, V., Ed.; The North Carolina Cooperative Extension Service: Raleigh, NC, USA, 1982.

39. Urban, L.; Brun, R.; Pyrrha, P. Water Relations of Leaves of 'Sonia' Rose Plants Grown in Soilless Greenhouse Conditions. HortScience 1994, 29, 627-630. [CrossRef]

40. Hermida, J.J.F.; Toro, M.C.H.; Guzmán, M.; Cabrera, R.I. Determining Nutrient Diagnostic Norms for Greenhouse Roses. HortScience 2013, 48, 1403-1410. [CrossRef] 